\title{
Modernising environmental regulation in Northern Ireland: a case study in devolved decision-making
}

\author{
Sharon Turner and Ciara Brennan
}

School of Law, Queen's University Belfast*

\begin{abstract}
Introduction
$\mathrm{F}$ or over a decade, controversy about the quality of environmental regulation has cast a shadow over the effectiveness of environmental governance in Northern Ireland. Most fundamentally this debate has centred on a crisis of confidence about the quality of regulation and a consensus that effective reform depends on the externalisation of this responsibility from central government. Not surprisingly, the causes of weak regulation were rooted in the eclipsing impact of the Troubles and the fossilisation of government that occurred during the decades of Direct Rule. ${ }^{1}$ However, although the first steps towards meaningful reform were eventually taken under Direct Rule, the restoration of devolution and the stabilising power-sharing process has meant that the trajectory of regulatory reform has been largely shaped by a devolved administration. The purpose of this paper is to examine the nature and implications of that process. Pressure for regulatory reform is an issue that has confronted both configurations of Northern Ireland's power-sharing Executive. Despite its brief and tumultuous lifespan, the first Ulster Unionist Party (UUP)/Social Democratic and Labour Party (SDLP)-led administration was immediately faced not only with the evidence of serious regulatory dysfunction but also the first stage of what became a concerted civil society campaign for independent regulation. The collapse of power-sharing did nothing to quell this pressure. Instead, when devolution was restored five years later the new Democratic Unionist/Sinn Fein-led administration was faced once again with pressure for regulatory reform. However, this time the case for independent regulation was supported not only by civil society, but also the overwhelming majority of stakeholders to this governance process, including all but one of the parties sharing power and all but one of the industries subject to environmental regulation. This consensus was furthermore
\end{abstract}

* School of Law, Queen's University Belfast, 27-30 University Square, Belfast BT7 1NN. Email: s.turner@qub.ac.uk and cbrennan12@qub.ac.uk

1 The impact of the conflict on environmental governance has been discussed in detail elsewhere. See, for example, S Turner and K Morrow, Northern Ireland Environmental Law (Gill and Macmillan 1997); K Morrow and S Turner, 'The More Things Change, the More They Stay the Same? Environmental Law, Policy and Funding in Northern Ireland' (1998) 10(1) Journal of Environmental Law 41-59. 
supported by an independent review of the arrangements for environmental governance that had been commissioned by the Direct Rule administration during the hiatus in devolution. ${ }^{2}$

Despite the cacophony of voices calling for structural reform, the newly restored devolved Executive proved unable to facilitate that process. The political dynamics of devolution combined with the arrangements for decision-making within the power-sharing Executive effectively enabled the largest party sharing power to unilaterally block reform. Although the new Democratic Unionist Minister for the Environment (then Arlene Foster) acknowledged the need for improvement in the quality of regulation and committed to investment in this context, her party opposed the externalisation of this function from the Department of the Environment (DOE) and thus the change viewed by their partners in the power-sharing Executive as the necessary foundation stone for credible regulatory reform. While this debate arguably demonstrated the coming of age of the environment as a mainstream political issue in Northern Ireland and, indeed, fostered a maturing of civil society in this sector, the devolved administration's handling of this issue provided a powerful and unsettling insight into the nature and culture of devolved government and governance. While the legacy of weak regulation inherited by the devolved administration can be blamed on years of conflict and political absenteeism during Direct Rule, the debate surrounding its modernisation makes clear that the very different but real democratic limitations inherent in the region's devolution settlement will also function to stifle political stewardship of the environment. Regrettably, but most inevitably, this will force judicial resolution of the core structural arrangements for delivering environmental regulation, and thus diminish democratic control of a key aspect of economic regulation in post-conflict Northern Ireland.

\section{Facing the legacy of neglect}

It is probably an understatement to say that when the Good Friday Agreement was signed in 1998 the state of the regional environment and the arrangements for its protection were at best marginal to the concerns of the negotiating parties, not least Northern Ireland's major political parties. The political challenges of peace-building and power-sharing not surprisingly dominated the agenda for Northern Ireland's first power-sharing Executive. However, despite these pressures and its brief lifespan, the first power-sharing Executive was nevertheless forced to immediately grapple with the consequences of decades of neglected environmental governance. In essence, the UUP/SDLP-led administration inherited a system of environmental governance defined by serious legislative antiquation and very weak regulation. However, the proverbial ink was scarcely dry on the Good Friday Agreement when it was also forced to confront the legal and financial consequences of devolved responsibility for that inheritance. During the $1990 \mathrm{~s}$, endemic failure by government in Northern Ireland to ensure the timely and complete transposition of EU Directives on the environment and failure to invest in the water and sewerage infrastructure necessary to ensure operational compliance with the Urban Waste Water Treatment Directive $91 / 271 / \mathrm{EEC}^{3}$ had led the EU Commission to commence numerous 'infraction' proceedings against the UK. ${ }^{4}$ By the time devolution was restored in 1998, UK central government and the new devolved administration faced a phalanx of serious and advanced

2 REGNI, Foundations for the Future: The Review of Environmental Governance (2007) $<$ www.doeni.gov.uk/foundations_for_the_future_-_final_report.pdf>, discussed in more detail below. See also S Turner, 'Laying the Foundations for a Sustainable Northern Ireland' (2007) 58 Northern Ireland Legal Quarterly 422-58.

3 OJ L135/40.

4 S Turner, 'Transforming Environmental Governance in Northern Ireland: Part One: The Process of Policy Renewal' (2006) 18 Journal of Environmental Law 55-87. 
EU enforcement proceedings. The profound impact of EU pressure in forcing the first power-sharing Executive to invest in an immediate and extensive process of environmental law reform has already been the subject of detailed analysis by the present authors. ${ }^{5}$ However, while the mutual exposure of UK central government and the devolved administration to the legal and potentially serious financial consequences of EU infraction action undoubtedly induced the political will necessary to deliver a major programme of legislative and infrastructural modernisation, a similar dynamic did not apply to the equally dysfunctional process of environmental regulation.

On one level the restoration of devolution also coincided with an unveiling of serious regulatory weaknesses. Within weeks of the signing of the Good Friday Agreement, the Northern Ireland Audit Office published the first detailed analysis of the state of water pollution regulation in the region. ${ }^{6}$ This report was essentially a searing analysis of failure by the DOE to discharge its responsibilities as Northern Ireland's environmental regulator; however, it was not an isolated publication. Instead it became the first in a series of highly critical reports published by the Audit Office, the Public Accounts Committee (PAC), the Northern Ireland Affairs Committee (NIAC) and the Criminal Justice Inspectorate (CJI) during the period 1998 to 2007 concerning the quality of environmental regulation in the region. Their cumulative critique laid bare a landscape of enduring and serious failure by the DOE to discharge almost every aspect of its duty as environmental regulator. ${ }^{7}$ The nature and scale of this dysfunction has already been the subject of detailed analysis by the present authors. ${ }^{8}$ Suffice it for present purposes to state that these reports revealed a catalogue of lax, fragmented, inconsistent and non-transparent regulation and a particularly problematic approach to enforcing the rule of environmental law. However, while the official scrutiny community operating in the region gradually documented the systemic scale of the regulatory dysfunction that pertained in Northern Ireland, it did not fall within the ambit of the EU enforcement action then underway. Thus, while the first devolved administration began to face significant internal pressure for regulatory reform, this did not extend to legal, financial or political pressure from the EU or Whitehall. In sharp contrast to the extensive modernisation programmes launched to overhaul the legislative framework governing the environment and the region's water and sewerage treatment infrastructure, the devolved administration's response to the evidence of seriously weakened environmental regulation revealed if anything, a willingness to exploit rather than resolve the problem.

The implications of weak regulation and in particular the centralised nature of this responsibility was cast into graphic relief by the manner in which the first power-sharing Executive handled the pressure to meet decades of unmet but not well aligned economic and environmental needs. On the one hand, the consolidating peace process and burgeoning property market on the island had fuelled escalating pressure for economic regeneration and development within the region. However, this pressure was arising in the context of a region with almost Victorian standards of water and sewerage infrastructure, which was itself the subject of concerted EU infraction action. ${ }^{9}$ The devolved Minister for

5 Turner (n 4).

6 Northern Ireland Audit Office (NIAO), Control of River Pollution in Northern Ireland, HC (1997-1998) 693.

7 Northern Ireland Assembly PAC, Third Report, Control of River Pollution in Northern Ireland (2001) <www.niassembly.gov.uk/public/reports/report3-00r.htm>; NIAO, Areas of Special Scientific Interest, HC (2003-2004) 499; House of Commons NIAC, Waste Management Strategy in Northern Ireland, HC (2004-2005) 349-I; House of Commons Committee of Public Accounts, Northern Ireland's Waste Management Strategy, HC (2005-2006) 74; NIAO, Northern Ireland's Waste Management Strategy, HC (2005-2006) 88.

8 S Turner, 'Transforming Environmental Governance in Northern Ireland. Part Two: The Case of Environmental Regulation' (2006) 18 Journal of Environmental Law 245-75, at 266-9.

9 Turner (n 4). 
the Environment (then Dermott Nesbitt, UUP) was consequently faced with expressions of serious concern by the Executive Agency within his department responsible for environmental regulation (then called the Environment and Heritage Service) as to the legal and environmental implications of permitting further development in areas lacking appropriate sewage treatment, while at the same time the Executive Agency within his department responsible for development control in Northern Ireland (the Planning Service) faced intense pressure to facilitate economic regeneration. Nesbitt made an initial decision to impose a moratorium on all development in what became known as sewage 'hotspots' to enable the department to consider the legal, environmental, economic and operational implications of this situation. However, this review resulted not in a decision to restrain development or even to require developers to share the costs of ensuring temporary sewage treatment for proposed development, but a decision to constrain the environmental regulator. Nesbitt acknowledged that serious and potentially irreversible environmental damage would be caused by further development in areas without appropriate sewage treatment. Although the devolved administration had already signalled its commitment to a major programme of infrastructure investment to respond to EU infraction pressure, it was also clear this process would take years to deliver. Consequently, the minister announced that the most 'pragmatic' solution was to enable the regulator to 'alert' the planning authorities to the environmental implications of proposed development but to prevent it from lodging a formal objection to the granting of development consent.

Quite apart from the disquiet caused by evidence of weak environmental regulation being delivered by the DOE, this decision cast into sharp relief the even more fundamental problem arising from the centralised nature of responsibility for this function. Despite the creation of independent regulators across the rest of the UK and Ireland during the 1990s, successive Direct Rule administrations had resisted pressure for equivalent structural reform in Northern Ireland. ${ }^{10}$ This function thus remained the responsibility of the DOE, and although delivered by an Executive Agency possessed of its own resources and staff, it lacked any separate legal identity. The 'hotspots' debacle highlighted not only the governance implications of centralised regulation, but also the willingness by Northern Ireland's new political class to exploit the weaknesses inherent in these arrangements in order to facilitate even crude economic development and build political capital. However, it also marked a turning point in the relationship between government and the region's environmental non-governmental organisation (ENGO) sector.

\section{A maturing of civil society}

In sharp contrast to their counterparts in the fields of human rights and equality in Northern Ireland and their sectoral counterparts in Britain, the ENGO sector on the island of Ireland is relatively underdeveloped. ${ }^{11}$ Environmental campaigning on the island has historically been characterised by an emphasis on highly localised campaigning; ${ }^{12}$ however, in Northern Ireland a range of distinctive factors flowing from the dynamics of Direct Rule had additionally forged an ENGO culture that valued access to government over robust public debate. In essence, the absence of accountability levers and the highly centralised nature of environmental governance under Direct Rule had created a strong disincentive to the high-

10 The reasons for which are discussed by Turner (n 4) 249-54.

11 See L Leonard, The Environmental Movement in Ireland (Springer 2007) and J Barry and P Doran, 'Environmental Movements in Ireland: North and South' in T McDonagh, F Varley and S Shorthall (eds), A Living Countryside (Ashgate 2009) 321-41.

12 Barry and Doran (n 11). 
profile public campaigning on the environment common in other UK jurisdictions. ${ }^{13}$ Direct Rule ministers were also frequently absent leaving civil servants to assume a greater responsibility for decision-making. ${ }^{14}$ However, the small scale of government and the heightened role of officials led many within the civil service to personalise public criticism of government activity. ${ }^{15}$ Direct Rule also made it unattractive for many of the UK's leading ENGOs to fund anything other than a relatively small presence in Northern Ireland. The organisational risks and operational burdens posed by public campaigning were further exaggerated for this small sector due to the absence of a key participant in the public debate; namely, the regulator itself. As civil servants, officials within the regulator could not publicly contradict either the Minister for the Environment or the wider government and thus could not represent the public interest in the environment.

When devolution was restored, the spirit of political optimism that surrounded the new power-sharing Executive but also the widely understood fragility of this process initially compounded this sector's innate aversion to criticising government. ${ }^{16}$ However, the spectacle of Nesbitt's blatant political interference in the process of environmental regulation prompted Friends of the Earth (NI) to accuse him of 'gagging' the regulator, and to mount the first highly critical campaign of public opposition ever launched by an ENGO in Northern Ireland. ${ }^{17}$ Although this more confrontational style of political campaigning certainly alienated senior officials within the department and initially their ENGO counterparts, ${ }^{18}$ ultimately it catalysed an important process of maturing within the sector as a whole. In the face of the DOE's failure to formulate a meaningful reform agenda to respond to the by then mounting evidence of regulatory dysfunction, Friends of the Earth led the formation of a coalition comprising the region's nine largest ENGOs for the purposes of launching a united public campaign for the externalisation of this responsibility to an independent environmental agency. The formation of this coalition was certainly facilitated by greater investment in regional capacity by the major national ENGOs, which flowed from their expectation that devolution would create a more fruitful political context for public campaigning. However, the decision to collaborate not only protected individual groups from government pressure but enabled the members of the coalition to find their separate and collective public voice and with it came a process of maturing within the sector. But perhaps even more importantly, the high-profile, four-year campaign they waged provided not only a policy leadership completely lacking within central government, but was successful in bringing the environment from the remote margins to the mainstream of the post-conflict political agenda emerging in Northern Ireland.

\section{Pressure for reform on the cusp of political transition}

Despite the collapse of devolution in October 2002, the campaign coalition was formally launched in 2003. ${ }^{19}$ Most fundamentally it argued that credible environmental regulation

13 These observations are based on interviews with senior figures in the ENGO sector in the region and the direct professional observations of Professor Turner during the REGNI process and during an extended secondment to the DOE as a senior legal adviser.

14 Turner and Morrow (n 1).

15 See $n 13$.

16 Ibid.

17 Turner (n 4).

18 Interview with former Director of Friends of the Earth; see also J Barry, “It Ain't Easy Being Green": Sustainable Development between Environment and Economy in Northern Ireland' (2009) 24 Irish Political Studies 45-66.

19 The coalition consisted of the Conservation Volunteers, Friends of the Earth, National Trust, Northern Ireland Environment Link, RSPB, Ulster Wildlife Trust, Wildfowl and Wetlands Trust, Woodland Trust and WWF. 
required the externalisation of responsibility for this function to an independent environmental protection agency akin to those already established in the UK and Ireland. However, the coalition commissioned an independent expert analysis of the various options for structural reform and used the resultant report as the basis for a formal public consultation exercise to assess stakeholder support for externalisation of this function. ${ }^{20}$ The responses received were also the subject of independent analysis, which reported overwhelming support for the transfer of this responsibility to an independent arms-length entity. ${ }^{21}$ Although stakeholders varied in their views as to the level of independence necessary for effective regulation, only one expressed strong opposition to externalisation per se; namely, the Ulster Farmers' Union, which argued that the existing system could be made to function effectively through a process of internal reform. ${ }^{22}$ However, as the campaign matured so too did the ENGO agenda. In 2005, the coalition hosted a Chatham House conference to discuss the options for and implications of structural reform, which was attended by senior officials from UK and Irish environmental regulators and core Northern Ireland departments engaged in environmental governance as well as senior representatives from the major regulated industries, the UK Sustainable Development Commission, UK Environmental Law Association, the UK judiciary, the office of the Northern Ireland Lord Chief Justice and leading academic commentators on this issue. ${ }^{23}$ The meeting debated and supported the coalition's proposal that significant structural change should be preceded by an independent expert review of the region's wider arrangements for environmental governance, on the grounds that decades of Direct Rule and conflict had significantly distorted this landscape. Direct Rule ministers indicated their support in principle, but were initially unwilling to instigate such a major process of reform because of the expectation that devolution would be imminently restored. However, by 2005, against a hinterland of apparently intractable deadlock in constitutional negotiations, the Direct Rule Environment Minister (then Jeff Rooker) announced his support for the creation of an independent Environment Agency and his decision to commission the independent review of environmental governance demanded by ENGOs. ${ }^{24}$

The Review of Environmental Governance (REGNI) formally commenced in January 2006. ${ }^{25}$ Consistent with its terms of reference, it was conducted in a participative manner and involved recorded public meetings with an extensive range of the key stakeholders to this debate, spanning not only civil society but also business, industry, almost all of Northern Ireland's political parties, government advisory bodies, local and central government and the environmental regulator itself. ${ }^{26}$ The final report of the review, Foundations for the Future: A Review of Environmental Governance, was published in June 2007.27 Although its recommendations spanned the entire governance regime, the report's core findings concerned the process of environmental regulation. The review concluded that the

20 R Macrory, Transparency and Trust: Reshaping Environmental Governance in Northern Ireland (2004) $<$ www.ucl.ac.uk/laws/environment/docs/NI_report.pdf>.

21 L Fawcett, Environmental Protection Consultation: Analysis of Responses (2004) <www.foe.co.uk/resource/ reports/liz_fawcett_report.pdf $>$ at 2. Responses were received from 42 NGOs, 39 individuals, 14 private sector companies and organisations, four political parties and three public sector organisations.

22 Ibid 8.

23 Under Chatham House rules individual delegates cannot be named.

24 Friends of the Earth Northern Ireland Newsletter, 'EPA Inquiry Begins' (2005) (11 Autumn) <www.foe.co.uk/resource/newsletters/northern_ireland_11.pdf>.

25 The panel was comprised of Professors Tom Burke (chair), Sharon Turner and Mr Gordon Bell (then the recently retired CEO of Liberty IT).

26 For a full discussion of the process see, Turner (n 2).

27 REGNI (n 2). 
present institutional arrangements for environmental regulation in Northern Ireland did not reflect the standards expected of modern environmental governance. First and foremost, it pointed out that the regulator's ability to command public confidence depended on its ability to act, and to be seen to act, in a consistent, fair and predictable manner. ${ }^{28}$ However, the review emphasised that the 'constant message' to the panel was of a loss of public confidence that this was in fact the case. ${ }^{29}$ Secondly, the review pointed out that officials working within the regulator are exposed to both a real and perceived conflict of interest in that, as departmental civil servants, they are accountable, through the Departmental Permanent Secretary to Ministers; thus their first priority is to serve the minister not the environment. ${ }^{30}$ It concluded that this situation inevitably raised the suspicion and the risk that regulatory judgment might be tailored to suit immediate political circumstances. ${ }^{31}$ Thirdly, the report concluded that extensive audit of the regulator's function carried out in recent years by the regional scrutiny community had created a persuasive body of evidence confirming the misplaced nature of the argument that the regulator's position within central government enabled it to exert greater influence on policy-making. ${ }^{32}$

In view of the prime importance of restoring public confidence in this critical governance process, REGNI recommended that responsibility for regulation should be externalised to an independent environmental protection agency and set out proposals for how the new entity should be structured. However, Foundations for the Future also recommended that significant steps should be taken to strengthen the regulator's ability to enforce the rule of environmental law. In this regard, it stated that one of the key operational characteristics the new agency should endeavour to rapidly acquire and be recognised as having acquired is the capacity to prosecute non-compliance when appropriate. $^{33}$ To this end the review recommended the creation of an integrated enforcement office within the agency, with control of prosecutorial decision-making and its own dedicated legal staff. ${ }^{34}$ However, the review also recommended that reform of the regulator be complemented by improved judicial handling of environmental prosecutions. Although it acknowledged that equivalent research on environmental sentencing to that undertaken in Great Britain did not exist in Northern Ireland, 35 the report nevertheless concluded that sufficient evidence of unacceptably low and inconsistent sentencing could be gleaned from official scrutiny analysis to merit the launch of a comprehensive programme of training by the Judicial Studies Board and consideration of the case for a specialised Environmental Tribunal for Northern Ireland. ${ }^{36}$

Four months later a second independent analysis of the regulator was published that chimed strongly with the messages conveyed by REGNI, this time by the CJI following a year-long investigation of the DOE's use of its criminal justice powers. ${ }^{37}$ Like REGNI, the CJI recommended a strengthening of the regulator's approach to enforcement. It

28 REGNI (n 2) para 5.2.

29 Ibid para 5.3.

30 Ibid para 5.11.

31 Ibid.

32 Ibid para 5.13.

33 Ibid para 5.37.

34 Ibid.

35 Ibid para 9.10.

36 Ibid paras 9.10-20.

37 The report contained an analysis of the performance of the department's three Executive Agencies, which included the environmental regulator but also the Planning Service and the Driver and Vehicle Agency: CJI, Enforcement in the Department of the Environment (2007) <www.cjini.org/TheInspections/InspectionReports.aspx>. 
highlighted not only the regulator's overwhelming reliance on a compliance-orientated approach to regulation ${ }^{38}$ but also that it shared the wider culture of the other executive agencies within the department in that it viewed enforcement as a peripheral activity. ${ }^{39}$ The inspectorate strongly urged a significant rebalancing of regulatory effort to ensure a more explicit and robust approach to enforcement and particularly to criminal prosecution. To this end it made extensive recommendations designed to ensure a far more integrated and transparent approach to enforcement and build capacity through investment in specialised skills and the forging of more effective relationships with key agencies within the wider enforcement community. However, it was also clear that the inspectorate's report was influenced by both the political shift that had led to REGNI and also its recommendations. While the CJI stopped short of joining the review and indeed other scrutiny and advisory bodies who by this stage had articulated their support for externalisation of the regulatory responsibility, ${ }^{40}$ its report nevertheless explicitly emphasised the need for clear procedures to ensure the independence of the enforcement function from political and other internal or external pressures. ${ }^{41}$ The inspectorate furthermore reflected not only an awareness of rising public and ENGO demand for more rigorous enforcement of environmental law 42 but also an explicitly stated expectation that REGNI would lead to significant reform and the view that it was thus timely to recommend changes to the delivery of the regulator's enforcement function. 43

\section{The impact of restored devolution}

Although both REGNI and the investigation by the CJI had been commenced during Direct Rule, their final reports were launched into a totally changed political context. A breakthrough in constitutional negotiations in 2006 had led to the signing of the St Andrews Agreement and the restoration of devolution in early 2007. However, while the first power-sharing Executive was led by the relatively moderate UUP/SDLP, this time it was led by the political polar opposites of Sinn Fein and the Democratic Unionist Party (DUP). Successive Assembly elections held in the run-up to restoration had resulted in the decimation of the political middle ground and concentration of power in the extremes of Northern Ireland's political spectrum. The running of the d'Hondt process ${ }^{44}$ resulted in Northern Ireland's largest party taking control of the DOE, thus leaving the DUP with responsibility for responding to the recommendations made by these reports. In June 2007, Foundations for the Future was formally presented to the new devolved Minister for the Environment (then Arlene Foster). Although the two largest parties in the power-sharing Executive were the only two who did not submit evidence to the review process, Sinn Fein had made public its support for the creation of an independent regulator; albeit on an all-

38 CJI (n 37) para 2.16.

39 Ibid xi.

40 House of Commons Select Committee on the Environment, Environmental Issues in Northern Ireland, HC 39 (Session 1990-1991); Northern Ireland PAC (n 7) para 42; NIAC (n 7) para 101; NIAO (n 7) paras 4.7-9; House of Commons Committee of Public Accounts (n 7) para 21; Waste Management Advisory Board, Northern Ireland Waste Management Strategy Review Report (2004) <www.doeni.gov.uk/niea/ wastemanagementstrategyreview.pdf $>$.

41 CJI (n 37) ix.

42 Ibid paras 2.19, 5.3.

43 Ibid vii.

44 Through which executive responsibility is allocated under the power-sharing arrangement. See, generally, D Horowitz, 'Explaining the Northern Ireland Agreement: The Sources of Unlikely Constitutional Consensus' (2002) 32(2) British Journal of Behavioural Science 193-220. 
island basis. ${ }^{45}$ The DUP, however, had remained ominously non-committal as to its position on the status of the regulator. ${ }^{46}$

In September 2007, the Northern Ireland Assembly made clear the strength of its support for independent regulation through the debate of a motion submitted by the Leader of the Alliance Party (David Ford, now Minister for Justice), 'call[ing] on the Executive to establish an independent Environment Agency', ${ }^{47}$ which was adopted without division, and included the defeat of a DUP attempt to amend the motion so as to deflect and postpone an unequivocal statement of political support for independent regulation. ${ }^{48}$ However, Foster waited a year before making her formal response to the review report, which came in the form of a statement to the Assembly made in May $2008 .{ }^{49}$ She also used this opportunity to make her initial response to the recommendations published by the CJI. The minister informed the Assembly that she and her party took the role of environmental governance 'too seriously' to externalise responsibility for this function to an outside agency and thus that it would not be transferred to an independent entity. ${ }^{50}$ For the reasons discussed below, the DUP's rejection of independent regulation was not unexpected; however, it was nevertheless intensely controversial. Quite apart from the fact that it signalled a halting of its government engagement with the ENGOs concerning the need for far-reaching regulatory reform, the reasons motivating this decision, and even more fundamentally the manner in which it was handled, provided an unsettling illustration of the style of governance that power-sharing had unleashed and also how its distinctive dynamics would shape the regional environmental agenda.

\section{THE POWER DYNAMICS OF DEVOLUTION}

First and foremost, the DUP's ability to impose what was effectively a unilateral decision, opposed by all of the other political parties sharing power, made real the well-documented anticipation that power sharing would lead not only to the carving up of power but also the replacement of one form of compromised accountability with another. ${ }^{51}$ The Executive Committee formed by the Northern Ireland Act 1998 to exercise executive authority under devolution comprises each of the departmental ministers and the First and Deputy First Ministers drawn from the five political parties sharing power. ${ }^{52}$ Although the Ministerial

45 Gerry Adams MLA, President of Sinn Fein provided his endorsement of the externalisation of regulation to an independent agency <www.foe.co.uk/resource/evidence/ni_epa_stakeholder_endorsement.pdf>.

46 DUP's 2007 election manifesto did, however, suggest the party was 'open' to considering the best mechanism through which to implement environmental law, at DUP, Getting it Right (2007) $<$ www.dup.org.uk/pdf/DUPManifesto2007LR.pdf> at 57.

47 Minutes of the Northern Ireland Assembly, Private Member's Business, 25 September 2007 $<$ http://archive.niassembly.gov.uk/record/reports2007/070925.htm\#4>.

4825 September 2007. Peter Weir MLA (DUP) sought an amendment of the motion which would have called on the Assembly to simply 'note' REGNI's recommendation for independent regulation but would have called for further work to be undertaken to identify the costs and benefits of structural reform before a decision could be taken.

49 Full Ministerial Statement on Environmental Governance <www.northernireland.gov.uk/news/newsdoe/news-doe-may-2008/news-doe-270508-environment-minister-cuts.htm>.

50 Ibid 3.

51 In other words, that devolution involved the replacing of the democratic deficit inherent in Direct Rule with the democratic deficit posed by power-sharing. For further discussion of this issue, see, for example, $\mathrm{R}$ Wilford and R Wilson, A Democratic Design? The Political Style of the Northern Ireland Assembly (Constitution Unit, University College London 2001) <www.ucl.ac.uk/spp/publications/unit-publications/74.pdf>; R Wilson, The Northern Ireland Experience of Conflict and Agreement: A Model for Export? (Manchester University Press 2010); R Wilford, 'Northern Ireland: The Politics of Constraint' (2010) 63(1) Parliamentary Affairs 134.

52 C Knox, Devolution and the Governance of Northern Ireland (Manchester University Press 2010) 24. 
Code of Practice 53 governing the committee's functioning is designed to inhibit the potential for ministerial 'solo runs', it nevertheless ensures only a very pale imitation of the Westminster concept of cabinet responsibility. ${ }^{54}$ On the one hand, the code provides that ministers must bring issues to the attention of the Executive for collective consideration in certain situations, including any matter that 'cuts across the responsibilities of two or more Ministers' or, those deemed 'significant or controversial' by the First and Deputy First Minister acting jointly. ${ }^{55}$ While the status of the regulator had certainly become a 'significant' and 'controversial' issue by 2008, the DUP's trenchant opposition to independent regulation made it unlikely that the DUP First Minister (then Ian Paisley) would have agreed to act jointly with his Sinn Fein Deputy First Minister (Martin McGuinness) to require Arlene Foster to bring this matter to the Executive Committee. However, decision-making concerning the status of the environmental regulator was also an inherently cross-cutting issue, particularly in the Northern Ireland context where regulatory responsibilities are exercised by at least three other government departments in addition to the Department of the Environment.

While there was little doubt that Arlene Foster was bound by the Ministerial Code to bring this matter to the committee for collective consideration, it was also clear that the DUP retained the power to impose a unilateral rejection of independent regulation despite universal political support for externalising this responsibility. Although the code requires the First and Deputy First Ministers to seek to ensure that decisions of the committee are reached by consensus, it also provides that where consensus proves impossible, a vote can be taken. However, where it is requested by any three ministers, the code also provides that the vote must be taken on a 'cross community basis', the rules for which require a weighted majority of both unionist and nationalist ministers. ${ }^{56}$ It was already clear that consensus on this issue was unlikely. Because the DUP then held five of the committee's 12 ministerial positions, had the issue been put to a vote, the party could insist that it be taken on a crosscommunity basis and, because they comprised over 40 per cent of its unionist membership, could defeat both a majority and even unanimous support for independent regulation within the Executive Committee.

However, despite concerted efforts by members of the Alliance Party to force a formal clarification of how the decision to reject independent regulation had been made, the Executive Committee refused to confirm that it was an issue that should have been brought to its attention for collective consideration, or even to clarify whether a vote had been taken. During the Assembly debate of Foster's decision to reject independent regulation, Alliance Party MLAs ${ }^{57}$ argued that this decision was inherently cross-cutting and thus sought clarification as to whether it had been brought to the Executive Committee for collective consideration. ${ }^{58}$ In response, Foster stated that while the committee had been informed of her decision 'out of courtesy', oddly she did not consider the matter to be a cross-cutting

$53<$ www.northernireland.gov.uk/index/ministerial-code.htm>.

54 Knox (n 52) 25 and Wilford (n 51) 146.

55 Knox (n 52) para 2.4(i) and (vi).

56 Para 2.12 of the Code of Practice provides that a vote taking on a cross-community basis shall be governed by s 4(5) of the Northern Ireland Act 1998, which in turn provides that 'cross-community support', in relation to a vote on any matter, means either (a) the support of a majority of the members voting, a majority of the designated Nationalists voting and a majority of the designated Unionists voting; or (b) the support of 60 per cent of the members voting, 40 per cent of the designated Nationalists voting and 40 per cent of the designated Unionists voting.

57 Member of the Legislative Assembly (NI).

58 Assembly debate <http://archive.niassembly.gov.uk/record/reports2007/080527.htm\#4> 7 (David Ford, Alliance Party) and 12 (Dr Farry, Alliance). 
one $^{59}$ - despite emphasising in a later part of her statement that externalising this responsibility would affect the powers of several other Northern Ireland government departments. ${ }^{60} \mathrm{~A}$ few days later, 30 MLAs supported another initiative mounted by David Ford MLA, this time a petition submitted under s 28B of the Northern Ireland Act 1998, which empowers Assembly members to seek a referral of a minister's decision to the Executive Committee where they are considered to have acted in breach of the code, or where a decision relates to a matter of public importance. Following consultation with Assembly parties, the Speaker formally confirmed that the matter had been deemed 'a matter of public importance' and thus that a valid petition had been lodged. ${ }^{61}$

Although MLAs were successful in forcing the Executive to formally consider the issue, the rules governing the matters that must be addressed by the committee when responding to an Assembly referral rendered this a pyrrhic victory. Consistent with s $28 \mathrm{~B}$, the committee simply confirmed its view that the minister's decision was not taken in contravention of the Code of Practice. It furthermore confirmed the committee's view that decisions relating to environmental governance were 'significant and controversial' and also that it 'had noted' Foster's decision to reject independent regulation. Crucially, the committee was not required to and did not take the opportunity to clarify whether the minister's decision had been taken with the Executive's support, or indeed even if a vote had been taken. Rather bizarrely, its response went on to state that future decisions by Foster's successor, concerning the implementation of the alternative reform agenda she proposed (outlined below), would be brought to the committee's attention on the grounds that they would require its specific approval under the Ministerial Code and s 28A of the Act. The extraordinary obfuscation surrounding how the decision to reject independent regulation was made effectively concealed the unedifying reality that had Foster been forced to comply with the terms of the Ministerial Code, the DUP could simply have used its tribal veto to impose a minority, unilateral position in the face of universal opposition by its partners in the power-sharing Executive. To add insult to political injury, Arlene Foster was furthermore shielded by her party from the consequences of this intensely unpopular decision by an immediate transfer to a new and more senior ministerial position leading the Department of Enterprise, Trade and Investment. ${ }^{62}$

However, quite apart from what this process revealed as to the nature of power-sharing and in particular the very constrained form of democratic accountability it entailed, it also underlined the DUP's pronounced antipathy to participative governance. ${ }^{63}$ Although Foster could not avoid making a formal written response to the recommendations of the CJI given that it was a report published by a statutory scrutiny body, the DOE did not provide the detailed response to the review of environmental governance that would normally have been expected upon receipt of a report commissioned by government. Indeed, it even failed to notify the chair of the review panel of the minister's intention to make a statement to the Assembly. However, Foster underlined her rejection of deliberative decision-making, and in particular the ENGO coalition, by also announcing that the Environment and

59 Ibid 7 (Minister for the Environment).

60 Ibid discussed below.

61 Under s 28B(3), confirmed on 9 June 2008, Speaker's Business <http://archive.niassembly.gov.uk/record/ reports2007/080609.htm\#2>.

6213 days later, on 9 June 2008.

63 Although the DUP is not alone in this position amongst the region's political parties, its particular hostility to the participative governance has been addressed by: C McCall and A Williamson, 'Governance and Democracy in Northern Ireland: The Role of the Voluntary and Community Sector after the Agreement' (2001) 14(3) Governance: An International Journal of Policy and Administration 363; and V Bell, 'Spectres of Peace: Civic Participation in Northern Ireland' (2004) 13(3) Social and Legal Studies 408. 
Heritage Service would be relaunched as the 'Northern Ireland Environment Agency' (NIEA). ${ }^{64}$ The cynical suggestion that the ENGO coalition's demands for independent regulation could be satisfied through a simple rebranding exercise was widely criticised, but, combined with the DUP's decision to replace Arlene Foster as Environment Minister with Sammy Wilson, an avowed opponent of the environment lobby and vocal climate sceptic, ${ }^{65}$ represented not only a powerful snub to the ENGO coalition but also an ultimately successful attempt to suppress this nascent lobby.

\section{THE IMPACT OF 'HIGH' CONSTITUTIONAL POLITICS}

Although Foster's rejection of the recommendation for independent regulation was largely an exercise in the use of crude political power, it was nevertheless clear that the decision was also strongly influenced by the 'high' politics of the constitutional transition, which concerned the commandeering of political power by the new administration but also the inherent fragility of power-sharing itself. From the outset of her statement to the Assembly, Foster characterised both REGNI and the CJI investigation as processes commenced during the Direct Rule period thus obviating a sense of political ownership as to their findings. ${ }^{66}$ However, the pronounced hostility directed towards the recommendations made by REGNI also stemmed from the distinctive political dynamics that had characterised the constitutional transition. Whereas policy stagnation had for decades been the traditional angle of repose under Direct Rule, the administration that governed Northern Ireland following the collapse of power-sharing in 2002, and particularly during Peter Hain's tenure as Secretary of State from 2005-2007, was defined by the proactive development of a series of major policy initiatives, notably the abolition of the $11+$ educational selection process, the introduction of domestic water charges based on the capital value of (then) escalating house prices, and proposals to significantly curtail Northern Ireland's historically lax rural development policies. ${ }^{67}$ All touched core cultural and economic nerves within the region. ${ }^{68}$

However, while the environment and the environment lobby were undoubted beneficiaries of this 'policy spring', the agricultural industry and landowners were notable losers, and at a time when advanced EU infraction pressure had also forced Northern Ireland to implement the EU Nitrates Directive on a 'total territory' basis, thus radically

64 Ministerial Statement (n 49) 3.

65 Sammy Wilson's hostility to the environment and climate lobby is well documented, for example, referring to the campaign to halt climate change as an 'hysterical pseudo-religion' at BBC News Online, 'Wilson Row over Green Alarmists', 5 September 2008 < http://news.bbc.co.uk/1/hi/7599810.stm>. His position in this regard has been furthermore covered in the ENDS Reports 401 and 402 and by The Guardian, 10 February 2009 <www.guardian.co.uk/politics/2009/feb/10/climate-change-sceptic-environment-minister>. Wilson's prioritisation of development over environmental protection in the field of planning is also well documented, for example: 'Government policy and decision making has been heavily influenced by the green lobby, which I believe has been detrimental to the British economy.' This position statement on the environment and a number of other areas is outlined on his DUP website <www.sammywilson.org/issues/>.

66 Ministerial Statement (n 49) 1.

67 The scale of opposition to more constrained rural development is outlined at <www.planningni.gov.uk/ index/policy/policy_publications/planning_statements/pps14/pps14_background.htm>.

68 Some sense of the scale of the political furore surrounding the planned introduction of domestic watercharging is provided in the Direct Rule administration's summary of the initial consultation responses at: Department of Regional Development, Integrated Impact Assessment of the Government's Proposals for Reform of Water and Sewage Services (2005) <www.drdni.gov.uk/iia_4-web_7_.pdf>, although this was also subject to intense media coverage and stakeholder litigation. Hain's decision to abolish the $11+$ is set out at <www.nio.gov.uk/media-detail.htm?newsID=13172>. Intense unionist opposition to this policy even threatened to destabilise power-sharing. A flavour of this debate is provided by $\mathrm{H}$ McDonald, 'Ulster Unionists Demand Deal on 11plus before Backing Power Sharing', 12 February 2010, The Guardian <www.guardian.co.uk/politics/2010/feb/12/ulster-unionists-demand-11plus-powersharing>. 
intensifying this industry's exposure to the costs and process of environmental regulation. ${ }^{69}$ In part, policy modernisation was motivated by UK Treasury demands that Northern Ireland pay its way and by Hain's particular interest in the environment. However, it was also perceived as a mechanism for mobilising local public pressure to render detachment from devolved power increasingly uncomfortable for local political parties, thus assisting in levering an end to the deadlock in constitutional negotiations that had kept devolution in suspension for five years. Not surprisingly, when devolution was finally restored in March 2007, environmental policy modernisation and the environment lobby became the subject of a pronounced political backlash from local politicians. The rejection of the high-profile campaign for independent regulation, like the immediate stalling of the other major policy initiatives progressed during Hain's term in office, ${ }^{70}$ became part of the political narrative that defined the restoration of devolution; namely, that power had been wrested from the resented Direct Rule administration. However, this decision was also used by the DUP to consolidate its particular relationship with one of its key political allies; namely, the agricultural industry, whose representative body (the Ulster Farmers' Union) had been alone in opposing the creation of an independent environment agency.

A final but critical factor militating against an immediate commitment to create an independent regulator concerned its potentially destabilising implications for the fragile arrangements created to support power-sharing. Although a reality only hinted at in the minister's statement, there was little doubt that externalising the Environmental and Heritage Service would have involved the removal of a significant part of the critical mass of the DOE thus undermining its viability as political portfolio. In addition, as Foster herself pointed out, three other Northern Ireland departments also exercised significant duties in this context. ${ }^{71}$ The creation of a coherent independent regulator would have confronted an inherently unstable administration with the immediate prospect of renegotiating how executive responsibilities should be reallocated across central government, whose original distribution had been informed not by concern to maximise policy synergies or regulatory outcomes, but to ensure that no one political party dominated the control of major policy sectors. ${ }^{72}$ Indeed, though many were sceptical of Foster's stated commitment to instigate an independent review of her decision in 2011, it was arguably an implicit recognition of the reality that a reconfiguration of central government would be more appropriate in the event that power-sharing proved sufficiently stable to survive at least the period of the first mandate.

\section{A new reform agenda emerges}

However, though Foster rejected the case for structural reform, she nevertheless appeared to acknowledge the need for improved regulation and used her statement to the Assembly to set out her own agenda in this regard. First, the minister acknowledged the need to improve the enforcement response to environmental crime $e^{73}$ and, secondly, announced her commitment to ensuring that environmental regulation would henceforth be premised

69 91/676/EEC. OJ L375/1. The significance of this approach to implementation is discussed by Turner ( $\mathrm{n} 4$ ).

70 Amongst the very first announcements made by the new devolved administration was its decision to halt the imposition of domestic water charges and to launch an independent review of the policy, 10 May 2007 $<$ www.iwrp-ni.org.uk/index/background.htm $>$. This was followed shortly afterwards by the launch of a review of Draft PPS 14 on rural development <www.planningni.gov.uk/ . . . /ministerial_statement_ pps14_251007.pdf>. The battle concerning the abolition of the $11+$ continues to be a source of significant disagreement between Sinn Fein and unionists and remains unresolved to the present day.

71 Ministerial Statement (n 49) 2.

$72 \operatorname{Knox}($ n 52), ch 2.

73 Ministerial Statement (n 49) 6. 
firmly on the principles of 'better regulation'. ${ }^{74}$ However, Foster also explicitly reassured the Assembly that she wished to 'see clear blue water between the role of the core Department as policy maker and legislator and the role of the NIEA as protector, regulator and enforcer'. ${ }^{75}$ Thus, she implicitly recognised that restoring the regulator's credibility would depend fundamentally on how well the DOE could assure the public and regulated community of the impartiality of regulatory decision-making. Although her immediate successor (Sammy Wilson) dismissed further calls by the Assembly later in 2008 for a commitment to externalise regulatory responsibility, ${ }^{76}$ arguing that a further review of the 'new' Agency was premature, ${ }^{77}$ sufficient time has now elapsed to consider whether the Ulster Farmers' Union were justified in their conviction that effective regulation could be ensured through a process of internal reform.

\section{SIGNS OF PROGRESS}

For almost all of the period since Foster's statement, the DUP remained in control of the DOE. Despite the disintegration of the ENGO coalition following the powerful rejection of its reform agenda, Foster and her successors (Sammy Wilson and Edwin Poots) worked to implement a reform agenda, which produced important advances in delivering a more robust regulatory response to the region's distinctive problems with waste crime. Whereas the sophisticated standards of waste regulation required under EU law had been implemented in Britain by 1990, over a decade elapsed before the equivalent controls were operationalised in Northern Ireland and then only in response to EU enforcement action. ${ }^{78}$ In addition to pressure to come to terms quickly with its new regulatory responsibilities, the regulator also faced an escalating problem of illegal transfrontier shipments of waste into the jurisdiction. By 2002, the combination of unprecedented volume of waste arising from Ireland's then 'tiger' economy, differences in the landfill taxes applying on each side of the Irish border, weak environmental regulation in both jurisdictions and an extensive land border had created the conditions for a highly profitable black market in illegal cross-border waste transport and dumping, which was being exploited on a significant scale by organised criminal gangs with possible paramilitary links. ${ }^{79}$

In order to respond to criticism of the regulator's failure to deal effectively with this problem, ${ }^{80}$ the Environment and Heritage Service established a dedicated Waste Crime Unit in 2004, which launched not only an intensive programme of criminal prosecutions ${ }^{81}$

74 Ministerial Statement (n 49) 3-4.

75 Ibid 6.

76 At the end of 2008 another Alliance Party motion was adopted by the Assembly (although amended by the SDLP), reiterating its concern at the minister's failure to create an independent regulator, expressing its view that the present entity was unable to meet the environmental challenges facing the region and calling for externalisation by the end of the first mandate: 11 November 2008 <http://archive.niassembly.gov.uk/ record/reports2008/081111.htm\#4>.

77 Ibid.

78 The legislative framework for applying modern waste management licensing in the jurisdiction was introduced with the enactment of the Waste and Contaminated Land (NI) Order 1997, but the transfer of responsibility for waste regulation from local government to the Environment and Heritage Service was not operationalised until 2003, Turner (n 4).

79 Discussed in particular by NIAC (n 7) para 88, Ev 203, Ev 6. Recent estimates suggest that between 2001-2004, approximately 8 per cent (approximately 250,000 tonnes) of the waste generated in Ireland was illegally dumped across the border in Northern Ireland. See T Hogan, 'Files will be sent to DPP on Illegal Dumping', Irish Independent, 7 May 2012 <www.independent.ie/national-news/files-will-be-sent-to-dpp-onillegal-dumping-3101771.html>.

80 Ibid NIAC. See also the discussion provided by the scrutiny reports on waste management (n 7). 
but also began to make innovative use of new financial investigation powers contained in the Proceeds of Crime Act 2002 in order to strip the profits from serious waste crime. Following an expansion of the range of statutory bodies permitted to use these powers in 2005,82 the DOE had applied for the accreditation of officials within the Waste Crime Unit. ${ }^{83}$ Working initially with the regional Assets Recovery Agency (ARA) from 2005-2008, the Environment and Heritage Service became the first environmental regulator in the UK to obtain a criminal confiscation order against a defendant convicted of serious waste crime, ${ }^{84}$ and by 2008 was the first such body to employ fully qualified financial investigators. Foster's statement to the Assembly highlighted these successes and committed to translating them across the agency as a whole. To this end she committed to establishing a dedicated Environmental Crime Unit (ECU), ${ }^{85}$ designed to provide the integrated enforcement capacity called for by REGNI and the CJI. In addition, she committed to a substantial programme of investment to support recruitment and training to develop its capacity. ${ }^{86}$ Although the dawning age of national austerity ultimately inhibited the full investment promised by Foster ${ }^{87}$ her successor Sammy Wilson oversaw the creation of the new ECU later in 2008. This unit now leads the UK in the use of financial legislation to strip the profits from serious waste crime. ${ }^{88}$ It has furthermore made concerted efforts to embrace the more sophisticated and intelligence-led approach to enforcement called for by the CJI, forged close partnerships with its Irish and UK counterparts and the specialised agencies engaged in tackling serious organised crime within the region, ${ }^{89}$ and has invested significantly in information management systems designed to enable it to collate data concerning those engaged in waste crime.

81 There were 24 prosecutions for waste offences in 2004, 61 in 2005 and 116 in 2006. This fell to 68 in 2007 , but increased slightly in 2008 to 74. These figures are based on information provided by the NIEA in 2011.

82 Pursuant to the Proceeds of Crime Act 2002 (References to Financial Investigators) (Amendment) Order 2005, No 386.

83 Accreditation was received from the National Policing Improvement Agency and further discussed by House of Commons NIAC, Third Report, Fuel Laundering and Smuggling in Northern Ireland, HC (2010-2012) 1504, Q410, Ev 72.

84 The case involved the illegal dumping of around 4000 tonnes of municipal waste from the Irish Republic in the early 2000s, which resulted in the making of a confiscation order of $f 80,868$ in September 2007 following the defendant's conviction in May 2006 for two counts of keeping and disposing of waste [2007] NICC 53.

85 Ministerial Statement (n 49) 6.

86 Ibid 3. It should be noted Foster did not disaggregate between the investment directed towards better

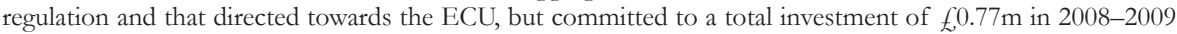
and $f 1.98 \mathrm{~m}$ in $2010-2011$.

87 While the ECU was designed to operate with a staff of 41, as of December 2011 only 25 staff were employed by the unit and the majority of vacancies existed at senior levels, although in early 2012 the new Minister for the Environment, Alex Attwood (SDLP), committed to hiring a further 11 staff. See BBC News Online, 'Northern Ireland environmental crime unit in recruitment drive', 23 December 2011 <www.bbc.co.uk/news/uk-northern-ireland-16321099>.

88 In partnership with the former Assets Recovery Agency (now the Serious Organised Crime Agency (SOCA)), NIEA secured a total of $£ 833,120$ in five confiscation cases. At the time of writing, NIEA's ECU has independently secured 10 confiscation orders subsequent to Crown Court convictions which total $£, 862,300$. In total, NIEA has through 15 confiscation cases secured $£ 1,695,420$ from convicted waste criminals. The confiscation regime has not yet been applied to environmental crime in Scotland thus far. Though the Environment Agency (EA) has recently started to make use of these powers, they have been used to a relatively lesser extent than in Northern Ireland. Information provided by the EA in March 2012 indicates that from 2006-2011, 38 confiscation orders have been made subsequent to EA waste prosecutions, but the vast majority (22) of these were in 2011 and 10 of those cases were for significantly smaller sums of under $f, 5000$. Source: information provided to the authors subsequent to requests made to the agencies under the Freedom of Information Act 2000.

89 In particular, the SOCA, HM Revenues and Customs, the Police Service of Northern Ireland and the Ports Authority. 
The second significant advance achieved under the leadership of DUP Environment Ministers concerns the DOE's success in forcing Ireland to accept its primary responsibility under EU Regulation 1013/2006 on the Shipment of Waste ${ }^{90}$ to repatriate waste illegally transported into the jurisdiction during the early part of this decade. Despite the DUP's constitutional hostility to the North South Ministerial Council, which had been created by the Good Friday Agreement to facilitate all-island co-operation in specified areas, Foster used this mechanism to negotiate a joint 'Road-Map' with her Irish counterpart to govern their respective responsibilities for the repatriation of this waste. The levering of agreement was undoubtedly aided by the application of legal pressure exerted by the EU Commission, which had commenced enforcement proceedings against the two governments due to their mutual failure to adequately control illegal transfrontier shipments of waste, ${ }^{91}$ and summonsed both to attend a trilateral meeting to discuss their plans for ensuring compliance. That said, the Road Map provided the basis of a successful defence to this litigation and the adoption of the formal bilateral framework agreement signed two years later by the two Environment Ministers under which Ireland formally accepted total responsibility for the cost of disposing of illegally dumped waste and 80 per cent of the cost of excavation, remediation and removal. ${ }^{92}$ Although the process of repatriation remains ongoing and is likely to take some years to complete, to date over 50,000 tonnes (out of an estimated 250,000) of waste have been transferred to Ireland at a cost of upwards of $€ 30 \mathrm{~m}$ to the Irish taxpayer. ${ }^{93}$

\section{A PARTIAL AND POLITICALLY MOTIVATED COMMITMENT TO ENFORCEMENT?}

However, despite the undoubted strides made in the context of enhanced waste enforcement, Foster's reform agenda has not been an unmitigated success in so far as the agency as a whole is concerned. Despite its official title, the new ECU was effectively a relaunching of the Waste Crime Unit. Instead of delivering the promised integration of enforcement efforts, its creation has intensified the fragmentation of enforcement efforts, a problem raised as a serious weakness by the CJI only a year earlier ${ }^{94}$ and acknowledged by the DOE. ${ }^{95}$ Responsibility for enforcing water and nature conservation controls remained with the Water Management Unit and a unit within the Natural Heritage Directorate respectively, ${ }^{96}$ while responsibility for waste enforcement was actually sub-divided between the new ECU and the Land and Resource Management Unit (LRMU), with the latter retaining responsibility for the enforcement of waste management licences. ${ }^{97}$ However, the

90 OJ L190/1.

91 IMPEL UPDATE (European Network for Implementation and Enforcement), June 2007 <www.rijksoverheid.nl/bestanden/documenten-en-publicaties/brochures/2007/08/01/newsletterenforcement-actions-third-edition/w986.pdf $>$.

92 <www.northernireland.gov.uk/news/news-doe/news-doe-june-2009/news-doe-120609-minister-announcesagreement.htm>.

93 Hogan (n 79).

94 CJI (n 37) 5, para 2.3.

95 DOE, Action Plan in Response to Criminal Justice Inspectorate Report on Enforcement within DOE (2008), at <www.cjini.org/CJNI/ files/b1/b169ceda-4e37-4448-b4a4-40e23b3f2419.pdf>.

96 As this article went to press, the authors were made aware that the ECU is in the process of expanding its portfolio of enforcement activity to include referrals from other units within DOE dealing with areas such as built and natural heritage crime. The nature and significance of these very recent changes will be analysed in a forthcoming paper by the present authors.

97 Although officials within ECU have indicated that its work more latterly includes cases against the holders of waste licences, they have also confirmed that the defendants are largely associated with organised criminal networks or operating on the periphery of the legitimate waste industry. It is worth noting that ECU and LRMU are currently negotiating a protocol to separate their respective responsibilities for enforcement. 
concentration of investment in enhancing the ECU's enforcement capacity has also created gaps and distortions in the agency's wider regulatory response, even in the context of waste enforcement. In 2007, a decade after the introduction of modern waste management standards, and a decade after the transfer of primary responsibility for waste regulation to the agency, the scale of its failure to implement this new regime was revealed by the CJI which reported that almost all of the landfill sites in Northern Ireland continued to operate without either planning permission or a waste management licence. ${ }^{98}$ Several other scrutiny reports were furthermore highly critical of the DOE's failure to finalise a protocol delineating the respective responsibilities of local government and the regulator for dealing with fly-tipping. ${ }^{99}$

However, despite the manifest need for balanced investment in supporting the agency in tackling the full spectrum of waste crime occurring in the region, and in coming to terms with its complex new responsibilities in this context, investment in enhanced waste enforcement has instead concentrated almost exclusively on enabling the ECU to respond to the enforcement failure for which the DOE was most severely criticised; namely, to take action against those responsible for illegal dumping on a commercial scale. ${ }^{100}$ This very narrow focus, combined with the ECU's concentration on using resource-intensive financial investigation procedures as the primary means of sanctioning serious waste crime, has resulted in a dramatic decline in the rate of prosecution and in the number of cases the unit can investigate at any one time. Although its earlier incarnation as the Waste Crime Unit had pioneered the use of financial investigation, it had also demonstrated a capacity to take a relatively high number of prosecutions, which rose from a standing start in 2003 to 116 prosecutions in 2006. In effect, the outworking of Foster's investment in the ECU has resulted, on the one hand, in increased investment in a specific form of enforcement expertise but, on the other, in a steep decline in the number of prosecutions being taken in relation to waste crime. By 2010, only 35 waste prosecutions were heard by the Northern Ireland courts. A year later the CJI published a follow-up to its 2007 report, ${ }^{101}$ which expressed concern about this pronounced narrowing of waste enforcement effort. While it acknowledged the unit's improved investigative approach to serious waste crime, the CJI also expressed concern that the concentration on using resource-intensive confiscation of assets powers as the primary approach to sanctioning meant it could only handle 16 live cases at any one time. ${ }^{102}$ However, the CJI also raised important concerns about the negative collateral impacts of this strategy on the rest of the agency's enforcement capacity, particularly on enforcement concerning the regulated waste industry. The inspectorate

98 CJI (n 37) para 2.23.

99 This issue has been raised in a number of the waste scrutiny reports ( $\mathrm{n} 7$ ) and more recently by the CJI (n 37) para 2.30. Evidence to the NIAC inquiry into fuel laundering and smuggling in January 2012 heard one MLA refer to 'passing the parcel' in terms of the blurred line between council and NIEA waste enforcement responsibilities, minutes available at <www.publications.parliament.uk/pa/cm201012/cmselect/cmniaf/ uc1504-vii/uc150401.htm at Q432>. In May 2012, the Assembly's Environment Committee again highlighted the need for a fly-tipping protocol, although it recognised progress had been made with a pilot being rolled out between NIEA and six local councils, see <www.niassembly.gov.uk/Assembly-Business/OfficialReport/Reports-11-12/15-May-2012/\#a5>.

100 This focus is explicitly acknowledged by NIEA in a number of publications, for example, NIEA, Compliance and Enforcement Report (2011) <www.doeni.gov.uk/niea/compliance_and_enforcement_report_2008_to _2010.pdf $>$ and in an NIEA briefing on establishing an integrated environmental crime unit from August 2008, see <www.doeni.gov.uk/niea/establishing_an_ect_-_december_2008_-_no_8.pdf>. It is furthermore emphasised by the CJI follow-up report in 2011, CJI, Enforcement in the Department of the Environment Northern Ireland: A Follow-up Review of Inspection Recommendations (2011) <www.cjini.org/CJNI/files/d7/d71473bc2dc9-4ff5-b957-d410ff851852.pdf >.

101 CJI (n 100).

102 Ibid para 2.15-16. 
highlighted not only that most of the LRMU's enforcement staff had been transferred to the new ECU, ${ }^{103}$ but also that this diminution of enforcement capacity has forced what remained of the LRMU to rely excessively on a compliance-based approach to regulation, characterised by a failure to prosecute even where this was acknowledged to be the most appropriate regulatory response. ${ }^{104}$ Similarly, although not raised by the inspectorate, the agency's continued failure to finalise a fly-tipping protocol with local government means that a significant category of illegal waste activity remains in a well-documented and strongly criticised regulatory limbo. ${ }^{105}$

While action to tackle serious waste crime was undoubtedly justified, Foster's highly partial approach to investment in enhanced enforcement raises a number of important questions not only about its regulatory outcomes but also its motivation. That reform of the agency's enforcement function was not designed to achieve better environmental outcomes is reflected in the fact that the net impact of the investment made has been to weaken the regulator's capacity to take enforcement action against the regulated waste industry, and to bring little if any positive impact on enforcement beyond the realms of waste crime. Instead, the distinctive focus of reform conveys the impression of a politically motivated enforcement agenda. Despite the minister's assurances that she wished to see 'clear blue water' between the departmental policy core and the agency's role as regulator, the exclusive investment in enhanced capacity to tackle serious waste crime, and exaggerated focus on supporting asset recovery procedures to sanction this activity, strongly reflects Foster's articulation of the reform required in that her statement to the Assembly specifically prioritised tackling serious waste crime and made clear her view that 'assets recovery is far more effective than court fines as both a punishment and a deterrent'. ${ }^{106}$ The impression of a politically driven enforcement agenda is further underlined by the fact that no additional investment was made in much-needed strengthening of the enforcement of environmental law in relation to legitimate economic activity, an approach that resonates strongly with the DUP's well-documented neoliberal economic agenda. ${ }^{107}$ Moreover, the NIEA's strong focus on high-profile criminal confiscation proceedings arguably serves to bolster the party's profile in stemming the revenue stream to organised crime and paramilitaries, and thus in countering destabilising forces within the region.

\section{A LIMITED CONCEPTION OF 'BETTER REGULATION'}

The second major stream of reform launched by Foster concerned her commitment to ensure that environmental regulation would henceforth be firmly premised on the UK and EU principles of 'better regulation'. 108 However, in this context it was clear from the outset that the NIEA would be embracing a selective conception of this paradigm, and furthermore that reform would bear the imprint of a distinctive political vision. That the shift to better environmental regulation would focus strongly on lightening the burden of regulation for industry, and in particular for the sector most trenchantly opposed to more effective regulation, was made clear by the immediate commissioning (in collaboration with the Department of Agriculture and Rural Development) of an independent review of the

103 These included the staff previously working on financial investigation and asset recovery litigation.

104 CJI (n 100) para 2.15.

105 Environment Committee (n 99).

106 Ministerial Statement (n 49) 5.

107 B Murtagh and P Shirlow, 'Devolution and the Politics of Development in Northern Ireland' (2012) 30

Environment and Planning C: Government and Policy 46-61; Barry (n 18).

108 Ministerial Statement (n 49) 3-4. 
administrative burdens falling on the region's agri-food sector. ${ }^{109}$ No equivalent review has been instigated for any other regulated industry; but this central emphasis is reinforced by the White Paper on Environmental Better Regulation published by the DOE in 2011, which provides a more detailed articulation of its plans concerning the embedding of this regulatory paradigm. ${ }^{110}$ But what this relatively brief White Paper also reflects is that the DOE simply plans to import the approach to reform used by the UK government to embed this regulatory paradigm in England and Wales without any consideration of the practical implications of doing so in a regulatory context characterised by a very weak deterrent to non-compliance.

The White Paper formally embraces the principles of better regulation developed by the Hampton ${ }^{111}$ and Macrory analyses, ${ }^{112}$ upon which the UK paradigm rests. In addition, it reflects their emphasis on the need to ensure that risk regulation is supported by an appropriately calibrated system of regulatory sanctions in order to ensure the existence of an effective deterrent. The White Paper goes on to set out a sanctioning reform agenda that is almost entirely derivative of Macrory's recommendations to the UK government in that it commits to the introduction of civil penalties and to the development and clarification of the courts' criminal justice powers. However, in doing so it strongly reflects Arlene Foster's marked unwillingness to embrace an evidence-based reform agenda in this context. Although scrutiny of the quality of environmental regulation over the past decade has focused almost exclusively on the role of the regulator, successive reports have expressed concerns about judicial handling of environmental prosecutions. ${ }^{113}$ REGNI explicitly concluded that, while the extensive empirical research conducted in the rest of the UK on environmental sentencing had not been paralleled in Northern Ireland, sufficient evidence existed to raise serious concerns about the quality of environmental justice being delivered in the jurisdiction. ${ }^{114}$ However, despite evidence indicating a compromised deterrent to environmental crime, and thus the likelihood that embracing risk regulation would pose distinctive challenges for the region, the DUP's determination to ignore the fact and regulatory implications of this glaring problem were clear from the outset.

During the Assembly debate of her decision to reject independent regulation in which she set out her plans for reform, the minister explained that she had sought the views of Northern Ireland's Lord Chief Justice as to the review's conclusions concerning the problematic nature of judicial sentencing. ${ }^{115}$ The minister referred to the letter she had received in response from the Lord Chief Justice, in which he is quoted as stating that ${ }^{\text {TT }}$ The report does not provide evidence to support this statement', 116 and furthermore that 'The very least one might have expected would have been for the group to have sought my views before making this bold statement.'117 By quoting this statement the minister effectively enabled the region's most senior judge to challenge the reality of inappropriate judicial

109 M Dowling, D Graham and B Jack, The Northern Ireland Agri-Food Better Regulation and Simplification Review (2009) <www.doeni.gov.uk/index/protect_the_environment/local_environmental_issues/better_regulation.htm>.

110 This was developed under the leadership of the most recent DUP Environment Minister, Edwin Poots. $<$ www.doeni.gov.uk/environmental_better_regulation_white_paper.pdf > .

111 P Hampton, Reducing Administrative Burdens: Effective Inspection and Enforcement (HM Treasury 2005).

112 R Macrory, Regulatory Justice: Making Sanctions Effective Final Report (Cabinet Office 2006).

113 House of Commons Select Committee on the Environment (n 40); NIAO (n 6) paras 8.15-17; PAC (n 7) para 36 and Minutes of Evidence paras 211-229; NIAO (n 7) para 3.25; CJI (n 37) paras 2.66-7.

114 REGNI (n 2) paras 9.10-20.

115 Minutes of the Northern Ireland Assembly, 27 May 2008 <http://archive.niassembly.gov.uk/ record/reports2007/080527.htm\#4>.

116 Ibid.

117 Ibid. 
sanctioning in environmental prosecutions. While there is little doubt that Foster was seeking to harness an influential voice in undermining the REGNI recommendations, when she added her own view that 'assets recovery is more effective than are court fines as a punishment and a deterrent', 118 the minister arguably exonerated the judiciary for refusing to use its powers to impose meaningful sanctions for environmental crime. In doing so she effectively punctured any incentive for officials to properly consider the implications of a weak deterrent for the principles of better regulation.

In the years since Foster's statement to the Assembly, the present authors have completed the first comprehensive empirical study of judicial sentencing for environmental crime in Northern Ireland. The confines of space prevent a detailed exposition of their findings, however, suffice it for present purposes to say that the research confirms, first and foremost, that REGNI's concerns about the quality of environmental justice were well founded. An analysis of 10 years of judicial sentencing from the late 1990s to the present day makes clear not only that sentencing for environmental crime in the jurisdiction is far below the statutory maximums in all key sectors, but also that it is remarkably out of line with the equivalent process in other UK jurisdictions. ${ }^{119}$ The research furthermore confirms that there is little if any meaningful deterrent to environmental crime in the region, and, in some contexts, arguably an incentive not to comply. While an eroded deterrent cannot be linked entirely to the absence of meaningful sanction, the experience of pronounced and entrenched resistance on the part of the judiciary to appropriately penalise environmental crime has undoubtedly played a pivotal role in achieving this outcome. This evidence consequently raises serious questions about the environmental and economic implications of the DOE's plans to import a regulatory paradigm designed for England and Wales where significant action has been taken over years to ensure that environmental crime is taken seriously by the judiciary and where the credibility of the regulator itself is not in question.

\section{Conclusion}

It is perhaps not surprising, given the foregoing analysis that the pressure for independent regulation has not gone away. While the first full mandate of devolved government has undoubtedly delivered some improvements in the quality of environmental regulation, there is significant evidence that reform of the agency's enforcement function has actually weakened its systemic capacity in this critical context. However, even more fundamentally, little has been done to rectify the perception of a politically captured regulator; if anything, quite the opposite. That independent regulation remains a live political issue was demonstrated vividly by the immediate resurfacing of this issue when control of the DOE passed from the largest party sharing power to one of the smallest following Assembly elections in 2011. Within weeks of his appointment, the new SDLP Environment Minister (Alex Atwood) announced his intention to publish a discussion paper to ascertain stakeholder views on the need to revisit this question. In August 2011, the DOE published Environmental Governance in Northern Ireland: A Discussion Document, ${ }^{120}$ which set out various options for structural reform of the regulator including the creation of an independent entity structured along the lines recommended by REGNI. ${ }^{121}$ The department's analysis of the responses received revealed not only that support for independent regulation in the

118 Ministerial Statement (n 49) 5.

119 The authors presented these findings in a seminar delivered to the Northern Ireland Judicial Studies Board (29 September 2011) and to an Enforcement Summit hosted by the Minister for the Environment (25 June 2012). They will also be the subject of a separate paper shortly to be submitted for publication by the current authors.

$120<$ www.doeni.gov.uk/env_gov_discussion_document.pdf>.

121 Ibid. 
terms recommended by REGNI remained very strong ( 83 per cent), ${ }^{122}$ but also that the dynamics of the debate remained unchanged. The Ulster Farmers' Union remained the only stakeholder to object to structural reform. Meanwhile the Assembly reflected its support for Atwood's process by adopting another motion submitted by the Alliance Party, this time noting publication of the discussion document, reiterating its view that environmental regulation should be independent and calling on the new Environment Minister to externalise the function. ${ }^{123}$

However, while the new minister has signalled his commitment to the creation of an independent environment agency, ${ }^{124}$ it is far from clear that he will be able to deliver this outcome despite the more favourable composition of the new Executive Committee. Whereas it was prepared to fudge how the decision was made in 2008 to reject externalisation, the Executive Committee itself has forestalled a repeat of this scenario. Quite apart from any arguments concerning the cross-cutting nature of this decision, the committee's response to the Assembly's referral of the matter explicitly confirmed that this is a 'significant and controversial issue', thus, Atwood will be required to submit proposals to deviate from this decision for collective consideration. The DUP remains in a position to insist that a vote concerning the creation of an independent regulator must be conducted on a cross-community basis. ${ }^{125}$ Crucially, though the balance of power within the Executive has more recently shifted in favour of those supportive of structural reform following electoral success by the Alliance Party, which resulted in its assumption of ministerial responsibility for the Department of Employment and Learning, but also the allocation of the new Department of Justice, to its leader (David Ford) - one of the most outspoken political proponents of independent regulation - even a decision by the two Alliance ministers to designate themselves as 'unionist' for the purposes of voting with the one UUP minister would still produce only 37.5 per cent of the 40 per cent support required amongst the unionists voting, thus enabling the DUP to block any move in this direction. ${ }^{126}$

However, where concerted political campaigning and the restoration of local democratic accountability have failed to induce meaningful leadership by the devolved Executive, it is almost inevitable that Northern Ireland's judiciary will be left to force what should have been a politically led process of reform. Within months of Foster's decision to reject independent regulation, the Northern Ireland High Court ruled on a judicial review in which the NIEA's position within central government was used as the basis for challenging the legality of draft Area Plans published by the Northern Ireland Planning Service. ${ }^{127}$ It was argued that the lack of functional separation between the plan maker and the authority designated under the Strategic Environmental Assessment Directive $2001 / 42 /$ EC $^{128}$ (SEA) as the environmental consultee (namely, the Planning Service and the NIEA, both executive agencies of the DOE) subverted the core mechanism created by

122 DOE, Synopsis of Responses to Discussion Paper entitled Environmental Governance in Northern Ireland (DOE 2011).

1235 September 2011.

124 For example, at a Northern Ireland Green Party Conference in October 2011, see his keynote address at $<$ http://greenpartyni.co.uk/green-party-ni-conference-2011/>.

125 The DUP continues to hold five ministerial positions in the new Executive. See also n 53 and associated discussion.

126 See n 56 and associated discussion. It is also worth noting that the DUP and Sinn Fein have recently announced proposals to disband the Department of Employment and Learning as part of a planned rationalisation of the region's elaborate central government arrangement, thus restoring the balance of power reflected in the first mandate.

127 Seaport (NI) Ltd, Magherafelt District Council and Others v Department of the Environment for Northern Ireland [2007] NIQB 62.

128 [2001] OJ L197/30. 
the directive to ensure environmental protection; namely, the environmental assessment of proposed plans and programmes. More specifically it was argued that these arrangements breached the implicit requirement that the assessment process should be based not only on consultation with the domestic authorities tasked with environmental responsibilities but also that they should be independent from the plan-making entity in order to ensure that the environmental information supplied is comprehensive and reliable. ${ }^{129}$ The High Court agreed with Seaport's interpretation of the directive ${ }^{130}$ and ruled that, if an independent environmental consultee did not exist, it may become necessary to create such an authority. ${ }^{131}$ On appeal, the Court of Appeal sought a preliminary ruling from the European Court of Justice as to whether the SEA Directive should be interpreted to require consultation with an independent environmental authority. The European Court did not embrace the High Court or Advocate General Bot's even more robust emphasis on the pivotal importance of consultation with an independent environmental authority as a prerequisite to ensuring the credibility and legality of the environmental assessment process. ${ }^{132}$ However, though it did not require that the entity be formally independent of the plan-making body, the court ruled that member states must ensure a sufficient degree of functional separation to enable the giving of an 'objective' opinion by the environmental authority. ${ }^{133}$ More specifically, it stated that the environmental authority must have 'real autonomy' and thus administrative and human resources of its own, ${ }^{134}$ but left it to the domestic court to make the final assessment as to whether these criteria could be satisfied in the circumstances of the case.

On one level, the European Court's ruling was a disappointment. The robust emphasis on the need for transparent, credible and thus independent consultation reflected in the High Court ruling and Advocate General's Opinion had raised hopes within the ENGO coalition that, despite its origins in a challenge to long overdue planning policy modernisation, this judicial review would ultimately provide an irresistible lever to force the externalisation of responsibility for environmental regulation. Without doubt it could always be argued that this case was an unlikely lever for achieving the creation of an independent environment agency called for by ENGOs. It was clear from the outset that even a European Court ruling requiring an independent environmental consultation body for SEA purposes could potentially have been satisfied by simply moving the officials responsible for area planning to another government department. However, there was also little doubt that explicit European Court confirmation of the need for an independent environmental consultation authority would have subjected the tribal veto of structural reform to important new pressure and potentially brought the political debate to a critical tipping point. That said the DOE's claim to have won this seminal legal battle is almost certainly premature. ${ }^{135}$ While the European Court's ruling was regrettably brief, it nevertheless drew a proverbial line in the legal sand concerning the governance arrangements required to facilitate the discharge of a key function performed by modern environmental regulators. It furthermore transferred responsibility to the national courts to

129 The arguments and decision in this case are discussed in more detail by S Turner, "The Strategic Environmental Assessment Directive: A Potential Lever for Independent Environmental Regulation in Northern Ireland?' (forthcoming) 24(2) Journal of Environmental Law.

130 [2007] NIQB 62.

131 Ibid para 17.

132 Case C-474/10, delivered 14 July 2011 (unreported).

133 Ibid para 42.

134 Ibid.

135 DOE issued a press release entitled 'DOE wins important European ruling', 20 October 2011 $<$ www.northerireland.gov.uk/index/media-centre/news-departments/news-doe>. 
make the final verification of whether the specific arrangements for functional separation at national level guarantee 'real autonomy' sufficient to enable the expression of an objective opinion. While the European Court was not prepared to comment directly on whether NIEA's status as an executive agency of the DOE enabled it to express an objective opinion on the environmental implications of plans proposed by another executive agency of the department, the Northern Ireland High Court squarely addressed this issue and in the negative. Weatherup explicitly ruled that as long as they remained part of the same department and legal entity, even a 'formal separation of roles' between these two executive agencies would not have satisfied him that sufficient separation was ensured to provide the nature and quality of consultation required by Article 6 of the SEA Directive. ${ }^{136}$

Regrettably Seaport Investments withdrew the judicial review and so the Court of Appeal was not ultimately required to rule on whether NIEA's status within the DOE enabled it to express an objective opinion on the environmental impacts of plans proposed by another executive agency of the department. However, it remains open to others to rely on the European Court's ruling and to use the NIEA's position within central government as a means to challenge decision-making by the DOE. In the meantime, the evidence of the NIEA's position as a captured regulator continues to mount. Despite the fact that the NIEA's lack of independence has cast a significant shadow over the credibility of this critical player in the process of regional environmental governance, it enjoys less functional separation within the DOE today than it did when the ENGO campaign began. During Sammy Wilson's tenure as Environment Minister, the roles of Chief Executive of the NIEA and the Deputy Secretary ${ }^{137}$ with responsibility for the department's core environmental and planning policy function were merged so that they are now held by the same official. In effect, the DUP has proved unwilling to maintain even the appearance of 'clear blue water' between the regulator and the departmental core. More recently the latest report from the CJI, published in 2011,138 also reflects entrenched political resistance to creating a transparent mechanism to protect the NIEA's independence even to take criminal enforcement decisions. While the department put in place a protocol governing external inputs into these decisions following the CJI report in 2007, its 2011 report notes that this protocol relates only to third parties but not to internal or ministerial interventions. ${ }^{139}$ The inspectorate accepted the minister's constitutional position in relation to control of decision-making within the department, but emphasised that staff must have the protection of 'a transparent decision-making process that is free from undue and inappropriate interference 140 and emphasised that procedures must be put in place to appropriately record ministerial involvement in decision-making by the regulator. ${ }^{141}$ Not surprisingly, this report also reflects the CJI's more explicit support for the structural independence recommended by REGNI in that this time the inspectorate points to the existence of independent regulators in all neighbouring jurisdictions and to Atwood's recent decision to re-opening the debate in Northern Ireland. ${ }^{142}$ Thus, while it seems highly unlikely that the DUP will permit the externalisation of responsibility for environmental regulation in the interests of effective environmental protection or as a concession to democracy, it is only a matter of time before the High Court and Court of Appeal are called on once again to

136 Para 15.

137 In effect, the grade below Permanent Secretary.

138 CJI (n 100).

139 Ibid para 2.40 .

140 Ibid para 2.43.

141 CJI (n 100) paras 2.43-6.

142 Ibid. 
consider whether the NIEA's status as an executive agency within DOE complies with the rule of EU environmental law. Given the serious reservations already expressed by Weatherup J and the CJI, and the NIEA's remerging into the departmental policy core, it seems inevitable that the judiciary will ultimately force the devolved administration to take the first meaningful step towards structural modernisation of Northern Ireland's environmental regulator. 